\title{
Ghosts, Stars, and Learning Online: Analysis of Interaction Patterns in Student Online Discussions
}

\section{Abstract}

Discussions are commonly used in online teaching and have been shown to foster student learning and collaboration. This case study uses content analysis to explore the interaction patterns of student online discussions during a semester-long teacher preparation course using concepts from sociometry. Findings suggest that interaction patterns were influenced by the content of student posts. Online discussions in this case were found to be an equitable form of collaborative learning, enabling each student to have a voice. There were, however, indications that gendered ways of knowing may play a role in the content of interaction, if not in the patterns themselves.

Keywords : Sociometry; online discussions; teacher preparation; interaction patterns; higher education; gender 


\section{Introduction}

Instruction in today's higher education classrooms has come a long way from the traditional lecture method, although it continues to be the dominant pedagogical approach (Barr \& Tagg, 2000; Pollio, 1984;Welty, 2000). The literature in teaching and learning emphasizes that students learn better when interacting with new ideas in a social context and constructing meaning from their experiences than they do passively receiving and being tested on knowledge transmitted by experts (Astin, 1993; Brooks \& Brooks, 1993). Dewey (1933) argued long ago that "learning is learning to think" (p. 78); in order to think one must be actively engaged in reflection. Vygotsky (1978) emphasizes the social context of thinking and learning by arguing that "learning awakens a variety of internal developmental processes that are able to operate only when the child is interacting with people and his environment and in cooperation with his peers" (p. 90). Although not children, there is support for the salience of the social context with adult students as well. Bruffee (1993), drawing on the work of Thomas Kuhn, Richard Rorty, and Clifford Geertz, argues that knowledge is socially constructed through interaction with peers.

\section{Literature Review}

The literature on effective teaching in higher education calls for students to spend more time learning through active engagement such as group discussions with their peers (Weimer, 2002; Fink, 2003). Pascarella and Terenzini (2005), in their seminal review of research on how college affects students, note that studies of innovative instructional approaches were largely absent from the body of research reviewed for the first volume of their work. Yet in the recently published second volume, they conclude that research evidence supports the effectiveness of instructional innovations such as collaborative and cooperative learning. The National Survey of Student Engagement (2007) found that academic success for adult learners is linked to social and academic engagement. Brookfield and Preskill (2005) argue that discussion can be used to further the goals of democracy in education by exposing inequitable power structures in the classroom that tend to silence students outside the dominant group. Given current demographic trends that show that non-traditional students are the fastest growing undergraduate population (Levine \& Sun, 2003), such approaches are important for the academic success of these students. As a result of research such as Gow and Kember (1994) that found that faculty who relied on lecture and a transmission approach to teaching were more likely to negatively impact the learning approaches of their students, college faculty are increasingly shifting their roles from the "sage on the stage" to a "guide on the side" (King, 1993; Weimer, 2002). 


\section{Group Discussions}

Group discussions are often used in online teaching and learning. Many studies have found that online group discussions facilitated student learning. Nicholson and Bond (2003) found that the reflective thinking of preservice teachers improved over the course of a 10-week field experience as they participated in online discussions. Other studies concluded that online discussions facilitate collaboration as well as encourage critical reflection (De Wever, Schellens, Valcke, \& Van Keer, 2006; Hawkes \& Romiszowski, 2001; Tutty \& Klein, 2008; ). Barnett, Keating, Harwood, and Saam (2002) found that preservice teachers began to explore their conceptions of inquiry and inquiry-based teaching through their online interactions using the Inquiry Learning Forum. Devlin-Scherer and Daly (2001) claim that online discussions improved the quality of both students and faculty in a teacher preparation course.

Levin (1999) analyzed the content and purpose of different types of electronic communication among preservice teachers. She concluded that web-based discussions "appeared to promote a reflective stance on personal, instructional, and critical issues by providing a community of peers who can be supportive, provide multiple perspectives, and give feedback to each other as they learn to teach" (p. 148). Schlagal, Trathen, and Blanton (1996) found that online discussions enabled joint construction of meaning among student teachers and their professors.

Given the growing use of group discussion both in face-to-face and online educational settings it is important to study what makes some discussions more effective learning experiences than others. Online discussions are unique in that they allow students time to reflect on their answers before posting. Likewise, students can take more time to understand and relate to what their peers have written because the posts remain accessible over time. Knowledgeable facilitation of online discussions by instructors has been found to be an important factor in successful online discussions (Andresen, 2009; Barnett, 2002; Collison, Elbaum, Haavind, \& Tinker, 2000; Oliveira, Tinoca, \& Pereira, 2011; Whipp, 2003).

\section{Women's Ways of Knowing}

When studying adult learning, it is important to consider gender. One of the most influential models of adult cognitive development is Perry's (1981) scheme of cognitive and ethical development. While the results have often been generalized to a wider population, the participants in the study were all male students at Harvard University. This study is focused on students in a teacher preparation program. According to the National Center for Education Statistics, in 2008, approximately $76 \%$ of all public school teachers were women. The majority of students in teacher preparation programs are also typically female (Commission on Teacher Credentialing, 2012). Research has shown that gender does influence learning in higher education (Astin, 1993). For example, studies have found that in math courses, beliefs about learning are more closely tied to female students' success than for male students (Kloosterman \& Stage, 
1991; Leder, 1992). In addition, studies have found gender influences in student interaction in online courses (Jeong \& Davidson-Shivers, 2006; Herring, 2003). Daugherty and Turner (2003) explored student popularity and group dynamics in a web-based environment and found that in a course with eight women and only three men, two of the men were ranked as the most popular students in the course, suggesting that gender may indeed play a role in online interactions. Guiller and Durndell (2006) found that women were more likely to express agreement in their online interactions, while men were more likely to express disagreement.The emphasis on beliefs and women's relation to knowing was first implied in Belenky, Clinchy et al.'s (1986) seminal study Women's Ways of Knowing. They found Perry's highly regarded (1981) scheme of cognitive and ethical development, based on research conducted on privileged male students, to be inadequate to explain their findings. Clinchy (2002) explains: "Perry's positions are defined mainly in terms of the nature of knowledge and truth...whereas we stress the women's relation to knowledge and truth, their conceptions of themselves as knowers" (p. 64). Their findings indicate that women's ways of knowing, or how they view the world of truth, knowledge, and authority, fit into five distinct perspectives: silence, received knowing, subjectivism, procedural knowing, and constructed knowing.

The silence perspective represents women who are not comfortable speaking or listening. Clinchy (2002), quoting Belenky (1996), describes the women of this perspective as lacking "the most basic tools for dialogue, the silenced feel voiceless and excluded from the community" (p. 394). Clinchy adds that the silence perspective doesn't even appear in theories of epistemological development, "for these theories are based on words-oral or written accounts-produced mainly by people with considerable formal education" (p. 65).

Received knowing is the second perspective of women's ways of knowing and is closely related to Perry's stage of dualism. Knowledge from this perspective is absolute; truth is external and is received from an authority figure. Clinchy (2002) sees this level frequently among her undergraduate students and sees her role as "to help students move beyond received knowing and on to more active, reflective modes of thinking" (Clinchy, 2002, p. 67).

The third perspective is subjectivism. Here, truth is now personal and internal like Perry's concept of multiplicity; "all opinions are equally valid, and everyone's opinions are right for them" (Clinchy, 2002, p. 69). According to Clinchy, women of a subjective perspective often are suspicious of information handed down by authorities. She points out that the openness of the subjectivist perspective is specious in that these women are not truly listening to the other points of view.

Procedural knowing follows subjectivism. Women who assume this perspective realize that not all opinions or answers are equally valid. "Knowing requires the application of procedures for comparing and contrasting and constructing interpretations, and the quality of the knowledge depends on the skill of the knower" (Clinchy, 2002, p. 73). 
The final perspective in Women's Ways of Knowing is constructed knowing. It is the most complex perspective of the five and was represented by only a small number of the participants. Like Perry's stage of relativism, people at this stage believe that all knowledge is constructed and recognize their own part in the construction of knowledge.

Nearly 20 years after Women's Ways of Knowing was first published, Clinchy (2002) is not sure that epistemological development is universally linear. While advocating further research, she especially cautions that domain specificity may influence epistemological development within particular disciplines. Belenky et al.'s work on women's epistemological development is particularly important for teacher education because the overwhelming majority of teachers and teacher candidates are women. If preservice teachers are to be educated to teach diverse learners in the $21^{\text {st }}$ century, something that requires constructed knowledge, attention must be paid to the teachers' epistemological perspectives.

\section{Sociometry}

Studies investigating student online interaction have used a wide variety of conceptual frameworks to guide the research. Henri's (1992) model is one of the first to look at the content of student posts. Her scheme of five dimensions includes participation, social, interactivity, cognitive skills, metacognitive skills. Another well-known model is Gunawardena, Lowe, and Anderson (1997) who focused on meaning negotiation and coconstruction of knowledge. Other studies adapted models from cognitive psychology and other fields. Samuels-Peretz (2012) adapted Kitchener and King's (2002) model of reflective judgment to analyze student learning in online discussions. Warren and Rada (1999) used Bloom's taxonomy. Pilkington and Parker-Jones (1996) developed the DISCOUNT model, derived from transactional analysis, dialogue game theory, and rhetorical structural theory and looks at purpose of student posts.

This study seeks to explore the role of group dynamics in online student interaction. Warren and Rada (1999) argue that student to-student feedback can support learning. Lee (1999) found that pre-existing social dynamics influenced student interaction in online discussions. Likewise, Oliveira, Tinoca, and Pereira (2011) found that social aspects and relational contexts can influence collaboration in online discussions. Given

such findings, it could be valuable to apply an approach to studying group dynamics in analyzing online discussions.

Moreno (1960) developed the concept of sociometry to study group dynamics and actions in social situations. In addition to enhancing our understanding of group processes, sociometry has given us tools for studying intergroup and interpersonal contexts (Evans, 1962), in particular, tools for collecting reliable data about groups. According to Evans, sociometry is particularly useful for studying classroom situations. Concepts used in such studies include: stars, students who are most frequently "liked" 
or nominated by others; isolates, students who are singled out negatively by peers; and ghosts, students who are ignored by their peers, neither chosen nor referred to.

Most studies that used sociometry to study interaction patterns and academic success were in elementary or middle school settings (Austin \& Draper, 1984; Li, 1985; Wentzel \&Asher, 1995). Only a few studies were found that used sociometry in a study of student interaction in higher education. Guldner and Stone-Winestock (1995) found that sociometric data on students and groups in their higher education students are significantly related to student learning. Daugherty and Turner (2003) conclude that sociometric measures can be a valuable tool for assessing online group dynamics among college students.Tools from sociometry can be helpful in uncovering student interaction patterns in online discussions. Who are the stars in an online discussion that enjoy multiple interactions? Who are the isolates and ghosts? Do stars get more out of a discussion because they interact more? Are ghosts at a disadvantage because they are not included in discussions? Such research would contribute to the knowledge base for online discussions. It could also be informative for instructors who use online discussion among their teaching and learning strategies.

This exploratory case study explores the following question: How might student interaction patterns in group discussion shed light on issues of teaching and learning? In particular, to what extent are there stars, ghosts, and isolates in an online discussion? In what way might frequency of interaction relate to the perceived quality of posts? What other patterns of interaction can be found in an online discussion and how might they relate to opportunities for socially constructed learning?

\section{Method}

This exploratory case study used content analysis as well as qualitative data analysis in order to analyze transcripts of online discussions. A case study design is particularly suited to questions of "how" or "why" and in situations over which the investigator has limited to no control, as in a classroom situation (Yin, 2003). The instructor of the course is also the researcher, making this an example of self-study research. Self-study is a type of practitioner inquiry in which university instructors make systematic inquiry into their own teaching practice (Dinkelman, 2003). Zeichner (1999) calls the emergence of self-study in teacher education "the single most significant development ever in the field of teacher education research" and notes that much self-study research explores the "nature and impact of teacher education activities" (p. 8). Self-study is closely related to action research in that it is a process of reflection and action that is designed to transform individual as well as collective experience; it is contextually rooted in one group at one particular time and place. Zeichner (1999) notes that much self-study research, such as the present study, explores the "nature and impact of teacher education activities" (p. 8). 


\section{Participants}

Participants, who gave informed consent, included all registered students in a semesterlong, undergraduate teacher preparation course at a private institution of higher education in the Northeast of the US. The participants were 10 White females, representing the typical student profile at this institution. It is also similar to national trends of students in teacher preparation programs who are predominantly White and female. Participants were in their junior of undergraduate studies pursuing a teaching license. The course focused on learning how to teach in elementary classrooms.

This case study draws on concepts from sociometry to study student interaction patterns.

While most sociometric studies, such as Daugherty and Turner (2003), use self-report data to determine group connections, this study focuses instead on the actual choices made during learning activities. The concepts of stars, ghosts, and isolates were used to analyze connections between participants and their ideas in each discussion. "Stars", in this study, indicate students who were referred to either by name, or by ideas contained in their posts, most frequently in a discussion. "Isolates", in this study, are students who were singled out for criticism or negative attention, either by name or by ideas contained in their posts. "Ghosts" indicate students whose posts are ignored by other participants and their posts in the discussion.

\section{Procedure}

Data collected included the transcripts for two online discussions for each of two groups, making a total of four online discussions. The discussions were conducted using a closed access learning management system. The discussions were required course assignments that each lasted for approximately 3-4 weeks and asked students to respond to a set of guiding questions for analyzing a case that dealt with ill-structured problems of practice in a typical elementary classroom. An ill-structured problem is one that has no single correct solution. There were only two online discussions in the course. The first case discussion focused on a teacher, Lee, who was trying to encourage one of her students, Rhonda, to read independently. The second discussion focused on a teacher who had twin immigrant girls in her class and was worried about the academic progress of one of them. To complete each discussion assignment, each student was required to post an analysis of the case based on the guiding questions, and then to respond to the posts of at least two group members.

Participants were divided into two groups of five students each, using purposive selection in order to ensure that they were comparable in terms of academic ability based on an ungraded, case discussion assignment that was conducted individually, on paper. This baseline case discussion was designed to be similar to the two online discussions and represented a typical ill-structured problem of practice in an elementary classroom. 


\section{Data Analysis}

The literature review has shown that learning is a complex phenomenon that may be addressed and evaluated in a variety of ways. The analytic strategy that drove this study was theoretical (Yin, 2003). According to Yin, an analytic strategy in a case study assists the researcher in determining what data should be analyzed, drawing conclusions, eliminating other possible interpretations, and even in selecting data sources. The theoretical analytic strategy is drawn from sociometry and the idea of studying the process of group discussion rather than the outcomes or content. In other words, this study isn't looking at what the students had to say about the cases in the online discussion, nor is it looking at evidence of learning how to teach. Instead, this study explores how the group members interact with each other while completing the online discussion assignment. Given the nature and focus of the research question, a combination of quantitative and qualitative approaches to data analysis offered the best means to address this inquiry.

\section{Quantitative data analysis.}

In order to explore the question, to what extent are there stars, ghosts and isolates in online discussions, student interaction in each discussion was analyzed using content analysis (Neuendorf, 2002). One of the main differences between content analysis and qualitative data analysis is the emphasis on reliability (Neuendorf, 2002; Rourke, Anderson, Garrison, \& Archer, 2001). Codes must be predetermined before analysis begins. Predetermined codes culled from the literature on sociometry were used in the coding process: stars, ghosts, and isolates. A percentage of interrater agreement was calculated based on a sample of the data that was coded by two raters. Interrater agreement was over $90 \%$.

Descriptive statistics, mainly frequency counts, were used for analysis. The number of times each group member, or her idea, was mentioned in another group member's post was counted in order to determine stars, ghosts, and isolates. An idea was defined as a suggestion, recommendation, or insight, with the sentence being the unit of analysis.

\section{Qualitative data analysis.}

Qualitative analysis was used in order to explore the following questions: In what way might frequency of interaction relate to the perceived quality of posts? What other patterns of interaction can be found in an online discussion and how might they relate to opportunities for socially constructed learning? Data were read and reread to acquire a general sense of patterns and themes. Transcripts of the online discussions were coded in an iterative process. Coded data were analyzed with the aim of organizing codes into categories. Memos were written throughout the coding and interpretation process aiding in the identification of patterns, regularities, and themes. 


\section{Findings and Discussion}

\section{Question 1: To what extent are there stars, ghosts, and isolates in the online discussions?}

In the first case discussion the students offered a variety of analyses and ideas for the teacher, Lee. These ideas ranged from adding more structure to independent reading blocks and connecting to Rhonda's interests, to creative solutions such as asking Rhonda to help her younger siblings learn to read. In the second case discussion, students noted that the teacher was comparing one girl's academic success to the other, forgetting that children, even twins, develop at their own rates. They also suggested confidence building activities to encourage the shy sister to speak more.

\section{Group 1 discussions.}

As can be seen in Table 1, all Group 1 participants were involved in the first discussion. Heather and Mia were stars, frequently referred to by other posts. Heather was referred to four times by name and six times by idea only. Mia was referred to three times by name and four times by idea only. There were no ghosts or isolates; everyone was referred to by a group member's post at least once.

Table 1

Participant References in Group 1 Discussion 1

\begin{tabular}{llllll}
\hline Student & $\begin{array}{l}\text { Referred to } \\
\text { by name }\end{array}$ & $\begin{array}{l}\text { Referred to } \\
\text { idea without } \\
\text { name }\end{array}$ & $\begin{array}{l}\text { Reference } \\
\text { expressed } \\
\text { support of } \\
\text { idea }\end{array}$ & $\begin{array}{l}\text { Reference } \\
\text { expressed } \\
\text { criticism of } \\
\text { idea }\end{array}$ & $\begin{array}{l}\text { Referred to } \\
\text { neutrally }\end{array}$ \\
\hline Heather & 4 & 6 & 6 & 1 & 1 \\
Peggy & 2 & 1 & 1 & & \\
Nicole & 1 & 0 & 1 & 1 & 2 \\
Mia & 3 & 4 & 6 & 1 & 2 \\
Lisa & 2 & 4 & 3 & & \\
\hline
\end{tabular}

The second discussion for Group 1 also showed a variety of interaction. Again there were no ghosts or isolates; no one was ignored or singled out for criticism. As can be seen in Table 2, there were two stars in the discussion, and they were not the same stars from the first discussion. Peggy and Nicole accounted for most of the references. Peggy was referred to twice by name and eight times by idea. Nicole was referred to five times by name and nine times by idea. 
Table 2

Participant References in Discussion 2

\begin{tabular}{llllll}
\hline Student & $\begin{array}{l}\text { Referred to } \\
\text { by name }\end{array}$ & $\begin{array}{l}\text { Referred to } \\
\text { idea without } \\
\text { name }\end{array}$ & $\begin{array}{l}\text { Expressed } \\
\text { support of } \\
\text { idea }\end{array}$ & $\begin{array}{l}\text { Expressed } \\
\text { criticism of } \\
\text { idea }\end{array}$ & $\begin{array}{l}\text { Referred to } \\
\text { neutrally }\end{array}$ \\
\hline Heather & 0 & 5 & 1 & 2 & 2 \\
Peggy & 2 & 8 & 4 & 3 & 0 \\
Nicole & 5 & 9 & 8 & 5 & 1 \\
Mia & 2 & 1 & 2 & & 0 \\
Lisa & 1 & 1 & 1 & 1 & \\
\hline
\end{tabular}

\section{Group 2 discussions.}

Group 2's discussions were also inclusive. Tables 3 and 4 show participant references in Group 2's first and second discussions. Lori and Ashley were stars in the first discussion, with five references to Lori and four to Ashley. The second discussion was even more active with three stars; Kelly and Lori were referred to five times each and Stacey was referred to four times. There were no isolates in either discussion, meaning there was no one singled out for a harsh, insensitive response. This is possibly due to student maturity and gendered concern for the feelings of others. As Guiller and Durndell (2006) found, women were more likely to express agreement than disagreement. There was, however, a ghost in the first discussion. Anne was not referred to by anyone in the first discussion.

Table 3

Participant References in Group 2 Discussion 1

\begin{tabular}{llllll}
\hline Student & $\begin{array}{l}\text { Referred to } \\
\text { by name }\end{array}$ & $\begin{array}{l}\text { Referred to } \\
\text { idea without } \\
\text { name }\end{array}$ & $\begin{array}{l}\text { Expressed } \\
\text { support of } \\
\text { idea }\end{array}$ & $\begin{array}{l}\text { Expressed } \\
\text { criticism of } \\
\text { idea }\end{array}$ & $\begin{array}{l}\text { Referred to } \\
\text { neutrally }\end{array}$ \\
\hline Lori & 5 & & 5 & 0 & \\
Stacey & 1 & 1 & 1 & 1 & \\
Kelly & 2 & 2 & & 1 \\
Anne & 0 & 1 & 3 & & \\
Ashley & 3 & 1 & & & \\
\hline
\end{tabular}


Table 4

Participant References in Group 2 Discussion 2

\begin{tabular}{llllll}
\hline Student & $\begin{array}{l}\text { Referred to } \\
\text { by name }\end{array}$ & $\begin{array}{l}\text { Referred to } \\
\text { idea without } \\
\text { name }\end{array}$ & $\begin{array}{l}\text { Expressed } \\
\text { support of } \\
\text { idea }\end{array}$ & $\begin{array}{l}\text { Expressed } \\
\text { criticism of } \\
\text { idea }\end{array}$ & $\begin{array}{l}\text { Referred to } \\
\text { neutrally }\end{array}$ \\
\hline Kelly & 2 & 3 & 5 & & \\
Anne & 1 & 1 & 2 & & \\
Lori & 1 & 3 & 4 & & \\
Stacey & 2 & 1 & 3 & \\
Ashley & 1 & 1 & 2 & & \\
\hline
\end{tabular}

\section{Question 2: In what way might frequency of interaction relate to the perceived quality of posts?}

\section{Group 1 discussions.}

Although there were not ghosts or isolates in the first discussion, Nicole was only referred to once in her peers' posts. This could be because she posted all her responses at the same time. Her lack of presence in the discussion over time could have led the other participants to not see her as an active member of the discussion. In the second discussion, Nicole was referred to five times by others. Unlike the first discussion, Nicole posted her responses over time, making her an active participant in the second discussion. This supports the earlier conjecture that her low involvement in the first discussion's interactions may be attributed to her having posted all of her responses at the same time. The fact that there were no isolates in either of the discussions suggests that the group interacted in a constructive way without offering destructive critique. In addition, no one person dominated the discussions for the group. Stars in one discussion gave way to new stars in the other.

\section{Group 2 discussions.}

Anne was a ghost in the first discussion. Examination of Anne's posts in the first discussion revealed that she did not offer any new comments or suggestions to the conversation. Most responses that refer to other group members focused on a unique idea they introduced. Since Anne's original post was the last one posted, her ideas were not new. Everything she wrote, such as that Lee should continue to work with Rhonda and her parents, had already been discussed in other posts. In addition, all of Anne's responses expressed agreement with other ideas without adding anything new that might engender a response. In light of these findings it is not surprising that Anne was a ghost in the discussion. Anne's posts seemed more to serve the purpose of completing the assignment rather than contributing in a meaningful way to the discussion. The picture changed in the second discussion when Anne recommended self-esteem boosting ideas in her initial post. This was a new idea for the group and as a result Anne was referred to twice in the discussion, making her no longer a ghost in the discussion. 
The analysis of interaction in the two groups shows the online discussions to be an inclusive mode of discourse that gave every student a voice. Every student was required to post, and every student did. The presence of the role of ghost or star related closely to the individual's contributions to the discussion. This suggests that the online discussions were not unduly influenced by external affective variables such as popularity and preexisting friendship. Had popularity been a factor, the interaction patterns would not have so closely aligned with the contribution of ideas to the discussion. Likewise, had friendships been a driving force, stars and ghosts would have remained similar in both discussions. Anne would not have been able to go from being a ghost in one discussion to being included multiple times in the second. There were no isolates in any discussion and the one ghost in one discussion was an active participant in the next discussion. This lack of a pattern favoring one star in a discussion or isolating one ghost supports the conclusion that contributions drove interaction in the discussion rather than popularity or friendship. If friendship or charisma had been the driving force of interaction a pattern of the same participants appearing as stars or ghosts would be expected.

\section{Question 3 : What other patterns of interaction can be found in an online discussion and how might they relate to opportunities for socially constructed learning?}

\section{Referring to participants by name.}

While analyzing the data to explore interaction patterns, some unanticipated themes emerged. An interesting theme in the discussions revolves around the use of names. For much of Group 1's first discussion, participants avoided using the names of other group members when referring to their ideas. Sometimes, as in the following example from Peggy's first response, the students used an anonymous term like "someone." Peggy wrote, "One suggestion was that peer pressure be applied as a method to get Rhonda interested" without naming Heather, who was the one who made that suggestion. Other students addressed ideas directly without referring to anyone at all as in the following quote from one of Heather's posts: "Though I recognize and sometimes think rhonda will grow out it. I, like lee's own sentiments, doubt if leaving rhonda alone during independent reading is such a good thing..." Heather was clearly responding to Lisa's suggestion that it may just be a phase Rhonda is going through, yet avoided mentioning Lisa at all.

It was not until Lisa joined the discussion that group members were mentioned by name. Lisa was the first to name whose idea she was responding to: "One idea presented by Peggy which involves incorporating Rhonda to read to her younger brother I think is a great way to develop this habit outside of the school setting." Nicole posted her first response after Lisa beginning, "I completely agree with you Heather." Peggy's and Mia's subsequent posts included names, but not for every reference. For the remainder of the semester, Group 1's online discussion posts frequently, though not always, mentioned 
members by name. Heather was the only group member that did not mention anyone by name during the entire first discussion.

In the second discussion, the participants continued to use names in their posts but only some of the time. Heather, Nicole, and Lisa, for example, each referred to a peer by name only once in the second discussion. There were far more references to ideas without naming the participant who suggested them. There were 10 named references altogether in the second discussion, but there were 23 unnamed references.

Three distinct patterns were found in the analysis of named references as opposed to unnamed references: direct responses to a post, ideas mentioned by more than one group member, and expressions of critique.

\section{Direct response to another post.}

The first naming pattern was when a participant seemed to be responding directly to a particular post, and the name was often, though inconsistently, omitted. A direct response to a post is indicated in WebCT by its use of threading. However, because the participants were not always aware of how their responses were threaded in WebCT, it is not enough to assume that a participant's post was a direct response to another post just on the basis of how it was threaded. The content of the post itself must imply that it is addressing a particular post rather than the whole discussion.

In the first discussion, Mia responded to Nicole's post on the use of reinforcements but did not use her name. Nicole wrote, "I think that reinforcement has been tried by Lee. Although it works for some students, it is not working for Rhonda." Mia's response clearly indicates that she was referring to Nicole's post even though she did not use Nicole's name: "I too feel that reinforcement may not be the best technique to use in order to get Rhonda to read." Mia did use Nicole's name when she later changed the topic to a different idea suggested by Nicole, further supporting that Nicole's name was omitted previously because it was a direct response. It is reasonable for participants to assume it would be clear to whom they are referring in a direct response to a particular post and would therefore omit the name. The omission of names in direct responses is frequent in these discussions, but there are cases where participants use names even in a direct response.

\section{Ideas mentioned by more than one group member.}

The second pattern of name use in the discussions was that when a participant was discussing an idea or comment mentioned by more than one participant, the names were often omitted. Peggy seemed to be speaking in a holistic sense when she wrote, "We seem to be mostly in agreement", and then, "I like the ideas of structuring Rhonda's reading time..." Also in the first discussion, Mia omitted names when she synthesized the responses she had read so far: "A couple of suggestions that seemed to run through several of the responses were to..." In the second discussion, however, she used names 
when she synthesized the responses so far. In the second discussion Lisa and Nicole both omitted names when referring to an idea discussed by more than one participant. It seems that some sort of group consciousness makes the need for names unnecessary when discussing ideas mentioned by the majority of group members. However, as Lisa's different use of names in summary posts in each discussion shows, this pattern is not consistent and there are a few examples of referring to individuals by name even for ideas discussed by many group members.

\section{And critiques shall remain nameless.}

The third and most consistent pattern was that when a participant was expressing some sort of critique of a peer's post, she always omitted the name. In the first discussion Peggy phrased a critique of Heather's suggestion to use peer pressure to encourage Rhonda to read without naming any names: "One suggestion was.. I can understand your thought process, but I don't know if it will work..." Heather, in turn, omitted names when she disagreed with Mia and Lisa's suggestion that Rhonda may "grow out of" her disinterest in reading without naming names: "Though I recognize and sometimes think rhonda will grow out it. I, like Lee's own sentiments, doubt if leaving rhonda alone during independent reading is such a good thing because of the distraction she poses to other students."

In the second discussion, each member made at least one unnamed critiqued of a group member's idea. There was a total of seven unnamed references to a group member's post in the second discussion. Perhaps participants omitted names when critiquing ideas to keep the discussion polite. By not singling out a member by name, the critic created distance between her critique and the person whose idea with which she disagreed. By keeping critiques impersonal, participants may perceive them as less offensive, and perhaps less damaging to fragile egos. This behavior could also be an indication that participants, who are all women, are moving away from subjectivism, where all opinions are equally valid, toward a procedural way of knowing where there is an awareness that knowing requires a process of evaluation and interpretation (Belenky, Clinchy, Goldberger, \& Tarule, 1997) but are not yet comfortable with the role of evaluating their peers' opinions.

Heather was unique in that she was the only person in the first discussion who did not mention a peer's name even once. At one point she even said "As was noted by some one (I forget who), it may be necessary to turn to other influences in Rhonda's life..." It is odd that Heather chose to omit the name and explain that she forgot it rather than just go back to the discussion and find the name of the person she was referring to. It could reflect laziness on Heather's part, or a simple lack of concern with the final form of her post. The text of the online discussion was easily accessible to her and would not have taken up much time. This could be an indication of the informal way participants viewed the online discussion assignments as opposed to the careful way they approached written assignments that were submitted. 
Lisa, on the other hand, always mentioned names when referring to someone else's idea in the first discussion. In the second discussion both Heather and Lisa each mentioned only one other by name in her posts. All other references to peers' ideas were unnamed. While Heather's omission of names was fairly consistent, Lisa began referring to peers' ideas without naming them only in the second discussion. Each instance where Lisa omitted a name fit in with one of the patterns reported above. Of Lisa's seven unnamed ideas, four were in reference to a critique, and three referred to an idea shared by more than one participant. Of the three patterns of naming, direct response, group ownership, and critique, only expression of critique was consistently unnamed in both discussions.

Group 2's use of names in reference to each other's ideas varied somewhat from that of Group 1's. In the first discussion there were only two unnamed references to another group member's ideas. One of these references was a critique, fitting in with the most consistent pattern evident in Group 1's discussions. Stacey did not refer to Kelly by name when she disagreed with her suggestion that Lee not pressure Rhonda in regard to reading: "I don't know if easing pressure off of Rhoda and her mother in regards to the importance of reading is the best plan of action." On the other hand, because Stacey's post was a direct response to Kelly's, she could have assumed that it was clear to whom she was referring, fitting the pattern where names were omitted in direct responses to a post.

\section{Limitations of Study}

The main limitation of this study is the small number of participants. Because it is an exploratory self-study that focused on the learning of a single class in an authentic higher education setting, the number of participants was limited by the enrollment of students in that particular semester. However this limitation also served as a strength by allowing a more in depth exploration of the interactions involved.

The fact that the instructor is also the researcher may be perceived by some to be an additional limitation. However, objectivity and generalization were not goals of this exploratory study. Instead, student interaction patterns were studied from multiple perspectives to see what might be learned. In such studies, the researcher's insider status can be an asset. A major criticism of self-study research reflects a positivist epistemology noting self-study's lack of generalizability (Zeichner \& Noffke, 2001). There are also issues of definition, methodology, and assumptions about the relationship between research and practice (Bullough \& Pinnegar, 2001; Cochran-Smith \& Lytle, 2004). In spite of such criticism, Cochran-Smith (2005) argues that such inquiry has "the potential to provide rich case studies and other close analyses of what teacher candidates learn, how they learn it, under what conditions, and how this learning is translated into professional practice" (p. 223). 


\section{Conclusions}

Several conclusions arise from the examination of student interaction patterns in this study. Among this group of college students, interaction patterns showed the group discussions to be equitable and focused on content rather than popularity. Stars in one discussion were not necessarily stars in another. There were no isolates, and the only example of a ghost was limited to a particular context where the student hadn't contributed something new to the discussion. Online discussion in this case study appears to be an effective learning tool allowing all students to participate equitably. Additional research would be able to explore this more fully.

The findings of this case study support the findings of Daugherty and Turner (2003) suggesting that sociometric tools of analysis can provide insight into the social aspect of teaching and learning in higher education. Further research can replicate the design of this study with additional groups of students, for further insight into student interaction patterns. Given the research emphasizing the role of social dynamics in student interaction (Lee, 1999; Oliveira, Tinoca, \& Pereira, 2011), sociometric analysis may be able to contribute to the literature.

The finding that students who did not contribute anything new to a discussion tended to be ignored, while those who offered new ideas and perspectives were referred to in subsequent posts, provides instructors with a valuable tool to support the learning of all students. By encouraging students to ensure their posts contribute to the discussion and by modeling how to do so, instructors can enable all students to be active participants in the discussion, thereby supporting student learning (Bain, 2004; Fink, 2003; Weimer, 2002).

It is interesting that every instance of a critique of an idea suggested by a participant was an unnamed reference. It seems that participants were uncomfortable critiquing their peers and avoided naming names in these cases. This aligns with literature that has found that women tend to perceive their roles as caring and empowerment of others which makes the expression of critique difficult (Belenky, Clinchy, Goldberger, Tarule, 1986). They have also been found to be generally more easily persuaded and tend toward consensus and closeness in conversations (Eagly, 1987; Guadagno \& Cialdini, 2002; Tannen, 1990).

It could also be that participants viewed critiques as hurtful and tried to distance critique from the person. As individuals who chose to prepare for a career aligned with caregiving, they may be uncomfortable criticizing others' ideas. If expression of critique is more difficult for women, the option to critique namelessly in online discussion may encourage freer expression. Given similar findings by Guiller and Durndell (2006), further exploration of student interaction patterns and gender is recommended. 


\section{References}

Astin, A. (1993). What matters in college. Four critical years revisited. San Francisco: J ossey-Bass.

Andresen, M. A. (2009). Asynchronous discussion forums: Success factors, outcomes, assessments, and limitations. Educational Technology \& Society, 12(1), 249257.

Austin, A. M., \& Draper, D. C. (1984). The relationship among peer acceptance, social impact, and academic achievement in middle childhood. American Educational Research J ournal, 21(3), 597-604.

Bain, K. (2004). What the best college teachers do. Cambridge, MA: Harvard University Press.

Barnett, M. (2002). Issues and trends concerning electronic networking technologies for teacher professional development: A critical review of the literature. Paper presented at the American Educational Research Association Annual Meeting, New Orleans, LA.

Barnett, M., Harwood, W., Keating, T., \& Saam, J . (2002). Using emerging technologies to help bridge the gap between university theory and classroom practice: Challenges and successes. School Science and Mathematics, 102(6), 299-313.

Barr, R. B., \& Tagg, J . (2000). Learning: A new paradigm for undergraduate education. In D. DeZure (Ed.), Learning from change: Landmarks in teaching and learning in higher education. Sterling, VA: Stylus Publishing.

Belenky, Clinchy, Goldberger, Tarule , (1986). Women's ways of knowing: The development of self, voice and mind. New York: Basic Books.

Brookfield, S. D., \& Preskill, S. (2005). Discussion as a way of teaching: Tools and techniques for democratic classrooms. San Francisco: J ossey-Bass.

Brooks, J . G., \& Brooks, M. G. (1993). In search of understanding: The case for constructivist classrooms. Alexandria, VA: Association of Supervision and Curriculum Development.

Bruffee, K. A. (1993). Collaborative learning: Higher education, interdependence, and the authority of knowledge. Baltimore, MD: J ohns Hopkins University Press.

Bullough, R. V., \& Pinnegar, S. (2001). Guidelines for quality in autobiographical forms of self study research. Educational Researcher, 30(3), 13-21. 
Clinchy, B. (2002). Revisiting women's ways of knowing. In B. K. Hofer \&P. R. Pintrich (Eds.), Personal epistemology: The psychology of beliefs about knowledge and knowing. Mahwah, NJ : Lawrence Erlbaum Associates, Publishers.

Cochran-Smith, M., \& Lytle, S. L. (2004). Practitioner inquiry, knowledge, and university culture. In J . J . Loughran, M. L. Hamilton, V. K. LaBoskey \& T. Russell (Eds.), International handbook of self-study of teaching and teacher education practices (pp. 601-649). Dordrecht: Kluwer Academic Publishers.

Cochran-Smith, M. (2005). Teacher educators as researchers: Multiple perspectives. Teaching and Teacher Education, 21(2), 219-225.

Collison, G., Elbaum, B., Haavind, S., \&Tinker, R. (2000). Facilitating online learning: Effective strategies for moderators. Madison, WI: Atwood Publishing.

Commission on Teacher Credentialing. (J une, 2012). CTC statistic of the month for J une 2012. http:// www.ctc.ca.gov/ educator-prep/ statistics/2012-06-stat.pdf

Daugherty, M., \&Turner, J . (2003). Sociometry: An approach for assessing group dynamics in web-based courses. Interactive Learning Environments, 11(3). 263-275.

Devlin-Scherer, R., \& Daly, J . (2001). Living in the present tense: Student teaching telecommunications connect theory and practice. J ournal of Technology and Teacher Education, 9(4), 617-635.

De Wever, B., Schellens, T., Valcke, M., \&Van Keer, H. (2006). Content analysis schemes to analyze transcripts of online asynchronous discussion groups: A review. Computers \& Education, 46, 6- 28. doi:10.1016/j.compedu.2005.04.005

Dewey, J . (1933). How we think: A restatement of the relation of reflective thinking to the educative process. Lexington, MA: D.C. Heath and Company.

Dinkelman, T. (2003). Self-study in teacher education: a means and ends tool for promoting reflective teaching. J ournal of Teacher Education, 54(1), 6-19.

Eagly, A. H. (1987). Sex differences in social behavior: A social-role interpretation. Hillsdale, NJ : Erlbaum.

Evans, K. M. (1962). Sociometry and education. London: Lowe \&Brydone LTD.

Fink, L. D. (2003). Creating significant learning experiences: An integrated approach to designing college courses. San Francisco: J osse Bass.

Gow, L., \& Kember, D. (1994). Orientations to teaching and their effect on the quality of student learning. J ournal of Higher Education, 65(1) 58-74. 
Guadagno, R. E., \& Cialdini, R. B. (2002 ). Online persuasion: An examination of gender differences in computer-mediated interpersonal influence. Group Dynamics: Theory, Research, and Practice, 6(1), 38-51.

Guiller, J ., \& Durndell, A. (2006). 'I totally agree with you': gender interactions in educational online discussion groups. J ournal of Computer Assisted Learning, 22(5), 368-381. DOI: 10.1111/j.1365-2729.2006.00184.x.

Guldner, C. E., \& Stone-Winestock, P. (1995). The use of sociometry in teaching at the university level. J ournal of Group Psychotherapy, Psychodrama \& Sociometry, 07311273, 47(4). 177-186.

Gunawardena, C. N., Lowe, C. A., \&Anderson, T. (1997). Analysis of a global online debate and the development of an interaction analysis model for examining social construction of knowledge in computer conferencing. J ournal of Educational Computing Research, 17, 397-431.

Hawkes, M., \& Romiszowski, A. (2001). Examining the reflective outcomes of asynchronous computer-mediated communication on inservice teacher development. J ournal of Technology and Teacher Education, 9(2), 285.

Henri, F. (1992). Computer conferencing and content analysis. In A. R. Kaye (Ed.), Collaborative learning through computer conferencing: The Najaden papers (pp. 115-136). New York: Springer.

Herring, S. C. (2003). Gender differences in CMC: Findings and implications. Computer Professionals For Social Responsibility Newsletter, 18 (1).

J eong, A., \& Davidson-Shivers, G. V. (2006). The effects of gender interaction patterns on student participation in computer-supported collaborative argumentation. Educational Technology Research \& Development, 54(6), 543-568. DOI 10.1007/s11423-006-0636-4

King, A. (1993). From sage on the stage to guide on the side. College Teaching, 41(1), 30-35.

King, P. M., \& Kitchener, K. S. (2002). The reflective judgment model: Twenty years of research on epistemic cognition. In B. K. Hofer \& P. R. Pintrich (Eds.), Personal epistemology: The psychology of beliefs about knowledge and knowing (pp. 37-61). Mahwah, NJ : Lawrence Erlbaum Assoc, Publishers.

Kloosterman, P., \& Stage, F. K. (1991). Relationships between ability, beliefs and achievement in remedial college-level mathematics classrooms. Research and Teaching in Developmental Education, 8(1), 27-36. 
Levin, B. B. (1999). Analysis of the content and purpose of four different kinds of electronic communications among preservice teachers. J ournal of Research on Computing in Education, 32(1), 139-156.

Levine, A., \& Sun, J . C. (2003). Barriers to distance education. Washington, DC: American Council on Educaton/ Educause. http:// www.acenet.edu/bookstore/ pdf/ distributed-learning/ distributedlearning-06.pdf

Leder, G. C. (1992). Mathematics and gender: Changing perspectives. In D. A. Grouws (Ed.) Handbook of research on mathematics teaching and learning (pp. 597622). New York: MacMillan.

Lee, I. S. (1999). A case study on the factors affecting Learners' discourse participation in a computer conferencing. In B. Collis \& R. Oliver (Eds.), Proceedings of World Conference on Educational Multimedia, Hypermedia and Telecommunications 1999 (p. 1705). Chesapeake, VA: AACE. Retrieved from http:// www.editlib.org/p/ 7236

Li, A. K. (1985). Early rejected status and later social adjustment: a 3-year follow-up. J ournal of Abnormal Child Psychology, 13(4), 567-77.

Moreno, J . L. (1960). The sociometry reader. Glencoe, IL: The Free Press.

National Center for Education Statistics. Fast Facts. Retrieved from http:// nces.ed.gov/ fastfacts/display.asp?id=28

Nicholson, S. A., \&Bond, N. (2003). Collaborative reflection and professional community building: an analysis of preservice teachers' use of an electronic discussion board. J ournal of Technology and Teacher Education, 11(2), 259280.

Oliveira, I., Tinoca, L., \& Pereira, A. (2011). Online group work patterns: How to promote a successful collaboration. Computers \& Education, 57(1), 1348-1357.

Pascarella, E .T., \& Terenzini, P. T. (2005). How college affects students: A third decade of research. San Francisco: J ossey-Bass.

Perry, W. G. (1981). Cognitive and ethical growth: The making of meaning. In A. W. Chickering (Ed.), The modern American college: Responding to the new realities of diverse students and a changing society (pp. 76-115). San Francisco: J ossey-Bass.

Pilkington, R., \& Parker-J ones, C. (1996). Interacting with computer based simulation: The role of dialogue. Computers and Education, 27(1), 1-14. 
Pollio, H. (1984). What students think about and do in college lecture classes. Teaching Learning Issues, 53. Knoxville, TN: University of Tennessee, Learning Research Center.

The National Survey of Student Engagement. (2007). Experiences that matter: Enhancing student learning and success, Annual Report 2007. Bloomington, IN: Center for Postsecondary Research. Retrieved from http://nsse.iub.edu/NSSE_2007_Annual_Report/docs/withhold/NSSE_2007 Annual_Report.pdf

Neuendorf, K. A. (2002). Content analysis. Thousand Oaks, CA: Sage Publications.

Rourke, L., Anderson, T., Garrison, D. R., \&Archer, W. (2001). Methodological issues in the content analysis of computer conference transcripts. International J ournal of Artificial Intelligence in Education, 12.

Samuels-Peretz, D. (2012). Nurturing preservice teachers' reflective judgment: Online discussion as a powerful teacher education tool. International J ournal of Instructional Technology and Distance Learning, 9(2), 41-53. Retrieved from http://www.itdl.org/Journal/Feb_12/Feb_12.pdf

Schlagal, B., Trathen, W., \& Blanton, W. E. (1996). Structuring telecommunications to create instructional conversations about student teaching. J ournal of Teacher Education, 47(3), 175-183.

Tannen, D. (1990). You just don't understand: Men and women in conversation. New York: Ballantine Books.

Tutty, J. I., \& Klein J . D. (2008). Computer-mediated instruction: a comparison of online and face-to-face collaboration. Education Techonlogy Research and Development, 56, 101- 124 DOI 10.1007/s11423-007-9050-9

Vygotsky, L. S. (1978). Mind in society: The development of higher psychological processes. Cambridge, MA: Harvard University Press.

Warren, \& Rada (1999). Manifestations of quality learning in computer-mediated university courses. Interactive Learning Environments, 7(1), 57-80.

Weimer, M. (2002). Learner-centered teaching: Five key changes to practice. San Francisco, CA: J ossey-Bass.

Welty, W. M. (2000). Discussion method teaching: How to make it work. In D. DeZure (Ed.), Learning from change: Landmarks in teaching and learning in higher education (pp. 186-191). Sterling, VA: Stylus Publishing. 
Wentzel, K. R., \&Asher, S. R. (1995). The academic lives of neglected, rejected, popular, and controversial children. Child Development, 66(3), 754-763. DOI: 10.1111/ 1467-8624.ep9506152723.

Whipp, J . L. (2003). Scaffolding critical reflection in online discussions: Helping prospective teachers think deeply about field experiences in urban schools. J ournal of Teacher Education, 54(4), 321-334.

Yin, R. K. (2003). Case study research: Design and methods (3 $3^{\text {rd }}$ ed.). Thousand Oaks, CA: Sage Publications.

Zeichner, K. M. (1999). The new scholarship in teacher education. Educational Researcher, 4-13.

Zeichner, K. M., \&Noffke, S. E. (2001). Practitioner research. In V. Richardson (Ed.), Handbook of research on teaching (4th ed., pp. 298-330). New York: American Educational Research Association/ Macmillan.

\section{Athabasca University}

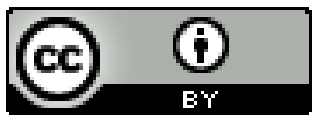

